\title{
Milliyetçiliğin Kökenleri: Etnisite/Ulus (Millet) İlişkisi
}

\author{
ABDULVAHAP AKINCI \\ akakinci1@yahoo.com.tr \\ ORCID ID: 0000-0001-9973-1118
}

Öz: Fransız Devrimi sonrasında hızla yayılan ideolojilerin başında yer alan milliyetçilik, haritaları ciddî boyutta değiştirdi ve yeni bir dünyanın ortaya çıkmasını sağladı. Devletlerin meşruiyetlerini sağlamada geleneksel araçlar yetmemeye başladı. Devletle birey arasında yeni bir bağ ortaya çıktı. Milliyetçilik modern dönem devletlerinde en belirgin hâle gelen araç konumuna yükseldi. Milliyetçilik tartışmaları olanca hızıyla sürmektedir. Milletlerin doğal bir olgu olduğu ve köklerinin çok eski döneme kadar gittiğini savunanların yanında milletlerin modern dönemde ortaya çıkan bazı sosyal, ekonomik ve kültürel şartlar altında inşa edildiğini iddia edenler de mevcuttur. Bazı düşünürler ise modern anlamda milletlerin bir inşa süreci sonucunda modern döneme ait bir olgu olduğunu kabul etmekle beraber millet inşa süreçlerinde etnik kökenlerin büyük bir etkiye sahip olduklarını ileri sürmektedirler. Bu çalışmada milletlerin ortaya çıkışı ile etnik kökenlerin bir bağlantısının olup olmadiğı irdelenerek milletlerin inşa süreçleri tartışılacaktır. Etnik kökenleri aynı olan toplumlar ile farkh etnik kökenden gelenlerden oluşan uluslararasında bir durum değerlendirmesi yapılmaya çalışılacaktır.

Anahtar kelimeler: Millet, Milliyetçilik, Ulus devlet, Etnisite.

\section{Giriş}

Modern dönemlerin en gözde tartışma konularından biri olan milliyetçilik üzerinde ortak bir tanım mümkün olamamıştır. Milliyetçiliğin tanımlanmasında ortaya çıkan en büyük farklılık kaynaklarından birini, milliyetçiliğin kökenine dönük tartışmalar oluşturmaktadır. Milliyetçiliğin hangi şartlarda, ne zaman ortaya çıktığ sorusuna verilen cevaba göre milliyetçiliğe ve dolayısıyla milletlere yüklenen anlam farklılaşmış olacaktır.

Milliyetçilik olgusunun 21. yüzyılda toplumlarda yükselen temel değerlerden birisi olma özelliği, bu konunun sağlıklı bir şekilde irdelenmesini zorunlu hâle getirmektedir. Toplumsal entegrasyon ve asimilasyon süreçlerinin olanca hızıyla devam ettiği modern ulus-devletlerde, sosyal bilimlerin farklı yönleriyle milliyetçiliği irdelemesi bir zorunluluktur. Bu konuda geniş bir literatür mevcut olmakla birlikte, konunun farklı bir gözle yeniden değerlendirilmesi faydalı olacaktır.

\footnotetext{
* Doç. Dr., Kocaeli Üniversitesi, İİBF, Siyaset Bilimi ve Kamu Yönetimi Bölümü.
} 
Bu çalışmada konu ile ilintili literatür taraması yapılmış ve etnisite-ulus ilişkisi irdelenmeye çalışılmıştır. Milliyetçiliğin kökeni ile modern ulus devletlerin ortaya çıkışı arasında bağlantı olup olmadığı ortaya konmaya çalışılmıştır.

\section{Milliyetçiliğin Kökenleri}

Millet kavramının tanımlanması konusunda ciddi zorluklarla karşılaşılmaktadır. Bunun en temel nedeni, Millet (Nation) kavramının genellikle içerik olarak "Devlet" ve "Halk" kavramları ile örtüşmesidir. Bunun yanında, çok farklı şekillerde tezahür eden milliyetçiliklerin ortaya çıkması da, tanımlamayı zorlaştırmaktadır. ${ }^{1}$

Milliyetçilik, bir entegrasyon ideolojisi olarak bir taraftan birliktelik duygusu ve bilincinin oluşmasını sağlarken, diğer taraftan da, ortak geçmiş, ortak düşmanlar, ortak amaç ve gelecek duygusunun oluşmasını sağlamaktadır. ${ }^{2}$

Milliyetçiliğin ne zaman ortaya çıktığı ile ilgili yoğun tartışmalar yapılmaktadır. Bu tartışmalar çerçevesinde milliyetçiliğin ne zaman ortaya çıktığına dönük üç farklı yaklaşım olduğu söylenebilir. Milliyetçilik kuramlarının birincisi ilkçi yani primordialist yaklaşımdır. İkincisi modernist yaklaşım, üçüncüsü ise etno-sembolcü yaklaşımdir.

İlkçi (Primordialist) Yaklaşım: İlkçi kavramı yerine özcü (essentialist) kavramını da kullananlar mevcuttur. ${ }^{3}$ İlkçilere göre milletler, doğal, sabit ve değişmez bir olgudur. Onlara göre milletler eski çağlardan beri mevcudiyetini sürdürmektedir. Bu yaklaşım aslında modernist yaklaşımın savlarını reddetmekte ve milletlerin belli bir dönemde belli şartlar altında ortaya çıkmadıklarını ileri sümektedir. ${ }^{4}$

İlkçilik içerisinde doğalcı, kültürel ve biyolojik olmak üzere üç farklı bakış açısı vardır. Bunların arasında ciddî yaklaşım farkları mevcuttur. İlkçilik içindeki en aşırı versiyonu oluşturan doğalcı yaklaşıma göre, etnik kimlikler, tıpkı duyu organlarımız kadar doğaldır. İnsanların hangi etnik kökenden oldukları önceden belirlenmiştir. İnsanlar bir etnik topluluğun bir parçası olarak dünyaya gelirler. Etnik gruplar ile milletler özdeş olarak kabul edilirler. ${ }^{5}$ Bu yaklaşımın etkisinin azalmasında en büyük etken, ulus olarak tanımlanmaya müsait olmayan devletlerin (Hindistan, Nijerya, Endonezya) ortaya çıkmasıdır. ${ }^{6}$ Zamanla bu yaklaşımın taraftarlarının önemli bir bölümü modernist yaklaşımı benimsemeye başladılar.

Biyolojik yaklaşım, etnik bağlılıkların kökenlerini genetik özellikler ve içgüdülerde

1 Kemal Bozay, “"Nation” und "Nationalismus” als Kernideologien der Herrschaftsabsicherung”, Ungleichwertigkeitsideologien in der Einwanderungsgesellschaft. Bozay K., Borstel D. (eds) Edition Centaurus - Jugend, Migration und Diversity., Wiesbaden: Springer VS, 2017, s.42.

2 Samuel Salzborn, "Nation und Nationalismus im 21. Jahrhundert", Staat und Nation. Die Theorien der Nationalismusforschung in der Diskussion, hg., Samuel Salzborn, Stuttgart: Franz Steiner Verlag, 2011, s.9.

3 Umut Özkırımlı, Milliyetçilik Kuramları; Eleştirel Bir Bakış, Ankara: Doğu Batı Yayınları, 2008, s.77.

4 Emre Gökalp, “Milliyetçilik: Kuramsal Bir Değerlendirme”, Anadolu Üniversitesi Sosyal Bilimler Dergisi, 7/1 (2007), s.281-282; Abdulvahap Akınc1, "Milliyetçilik Kuramları", C. ̈̈. İktisadi ve İdari Bilimler Dergisi, 15/1 (2014), s.139.

5 Özkırıml, Milliyetçilik Kuramları, s.83-85.

6 Anthony D. Smith, Ulusların Etnik Kökeni, çev., Sonay Bayramoğlu ve Hülya Kendir, Ankara: Dost Kitabevi Yayınlar1, 2002, s.29. 
aramaktadır. Onlara göre insanı yönlendiren en önemli güdü, üremede başarılı olma güdüsüdür. Özkırımlı’ya göre, ${ }^{7}$ bu güdüler insanları kendi yakın ve hısımları ile eşleşmeye yönlendirir. Bu içgüdüden dolayı bireyler kendi milletlerine ve etnik gruplarına çok güçlü duygularla bağlanırlar. Kültürel ilkçiliğin temel yaklaşımına göre birincil bağlılıklar, ilk olma özelliğine sahip oldukları için, her şeyden önce mevcuttur. Birey içinde yaşadığı toplumun alışkanlıklarına bağlılık duyar. Bireyleri topluluğa bağlayan herhangi bir çıkar duygusu değil, bir heyecan ve duygudur.

Modernist Yaklaşım: Modernist yaklaşım, akademik dünyada ilkçi yaklaşımın etkisini yitirmesine etki etti. Aralarında ciddî görüş farklılıkları bulunmakladır. Modernist olarak adlandırılan teorisyenlerin en tanınmışları arasında Gellner, Anderson, Hobsbawm, Balibar, Bhabba, Breuilly, Nairn, Brass, Hroch ve Chatterjee yer almaktadır. Modernistlere göre, millet olgusunun kökleri, ilkçilerin iddia ettikleri gibi eski dönemlere gitmemektedir. Milletler, modern çağın bir ürünü olarak ortaya çıktı. Milletlerin ortaya çıkmasında sanayileşme, merkezî devletlerin ortaya çıkmas1, kentleşme, laikleşme gibi etkenler belirleyici oldu. Modernistlere göre milletler, milliyetçilik çağının bir ürünüdür. Milliyetçilik, milletleri yaratmıştır. ${ }^{8}$ Milletler, kendi devletlerini kurmamışlardır. Tam tersine modern devletler kendi milletlerini inşa etmişlerdir. ${ }^{9}$ Genel kabul gören görüşe göre uluslar, milliyetçilik tarafından inşa edilmiş bir kurgudan ibarettir. ${ }^{10}$ Anderson'a göre, ${ }^{11}$ milletler, hayal edilmiş olan siyasî topluluklardır; yani hayalî cemaatlerdir. Milliyetçilik bu bağlamda yapay bir ideoloji olarak görülür.

Etno-Sembolcüler: İlkçiler ile modernistler arasında orta yerde duran etno-sembolcü yaklaşımın en bilinen temsilcisi Smith'dir. Smith, modernistler gibi milletlerin modern bir olgu olduğunu ve bir ideoloji hâline gelmesinin ancak 19. yüzyıl sonrasında gerçekleştiğini savunmaktadır. O, modernistlerden farklı olarak, özellikle Avrupa ve Orta Doğu’da kökleri yüzyıllar öncesine uzanan etnik topluluklar olduğunu ve bu etnik topluluklar ile modern milletler arasında bir bağ bulunduğunu savunmaktadır. Smith, her ne kadar modern milletler ile etnik topluluklar arasında bir bağ kurmasa ve hatta birçok etnik topluluğun millet hâline dönüşemediğini belirtse de, modern milliyetçiliğin ve milletlerin meydana gelmesinde eskiden gelen etnik toplulukların etkisinin olduğunu savunmaktadır. Smith'e göre modern milletler, kendilerini önceleyen etnik topluluklar anlaşılmadan anlaşılamaz. ${ }^{12}$ Etnik olarak aynı kökenden gelen toplumlarda uluslaşma süreci daha başarılı bir şekilde sonuçlanmıştır.

Milliyetçiler, kendi milletlerinin kökeninin çok eski dönemlere kadar gittiğini ispat

\footnotetext{
7 Özkırımlı, Milliyetçilik Kuramları, s.89-91.

8 Ernest Gellner, Uluslar ve Ulusçuluk, çev., Büşra Ersanlı Behar ve Günay Göksu Özdoğan, İstanbul: İnsan Yayınlar1, 1992, s.105.

9 Abdulvahap Akıncı, "Modern Ulus Devletlerin Doğuşu”, Dumlupınar Üniversitesi Sosyal Bilimler Dergisi, 34 (2012), s.142.

10 Ernest Gellner, Milliyetçiliğe Bakış, çev., Simten Coşar, Saltuk Özertürk ve Nalan Soyarı, İstanbul: İletişim Yayınları, 1998, s.59.

11 Benedict Anderson, Hayali Cemaatler; Milliyetçiliğin Kökenleri ve Yayılması, çev., İskender Savaşır, İstanbul: Metis Yayınları, 2. bs., 1995, s.20-22.

12 Anthony D. Smith, Milli Kimlik, çev., Bahadır Sina Şener, İstanbul: İletişim Yayınları, 4. bs., 2007, s.32.
} 
etmeye çalışırlar. Bu bağlamda kendi milletlerinin ortaya çıkışının diğer milletlerden çok daha eskiye dayandığını ispat etmeye çalışırlar. Bu durumu ispat etmek için kullandıkları araçların başında, milli mitoloji ve milli tarih gelmektedir. ${ }^{13}$

\section{Etnisite-Ulus İlişkisi}

Atalara ait bir miras olarak kabul edilen bir topluluktan geldiklerine inanan kimseleri belirtmek için kullanılan "etnisite" kavramı, eski Yunancada kullanılan "ethnos" (halk) sözcüğünden türetilmiştir. ${ }^{14}$ "Ethnos”, atalardan gelen ortak kültür anlamına gelmektedir. Bu kavramı biyolojik anlamda anlamamak gerekir. Burada kökenden kasıt sosyolojiktir. ${ }^{15}$ Kan bağı birliğine dayalı ortak birlik için eski Yunancada kullanilan kavram "genos"tur. ${ }^{16}$

Baumann’a göre etnisite aynı kandan gelindiği anlamına gelmemektedir: ${ }^{17}$

“Etnisite, doğanın kendi işleyişinin değil insanların eylem ve özdeşleştirmelerinin bir ürünüdür. İște bu nedenle etnisite aynı kandan ya da soydan gelmek değildir. Daha çok, doğanın başta verdiği ancak sonlandırmadığı tüm olanakların yetiştirilmesi ve rafineleştirilmesidir... çeşitli nedenlerden dolayı onu şaraba benzetmeyi seçtim. Şarap üzümden yapılır ve tıpkı etnik kimliklerin genelde atalar ve soyları arasındaki doğal bağlarla ilişkilendirildiği gibi doğal bir ürün olarak bilinir. Ancak doğanın kendisi şarap yapmaz, tıpkı soyun kendi başına etnisiteyi üretemeyeceği gibi... etnisite de yaşandığı toplumsal iklime bağlı olarak farklı anlamlar ve yan anlamlar kazanır. Tamamen durum ya da bağlama bağlı olarak etnik kimlikler vurgulanabilir ya da önemsizleşebilir; gururla ya da memnuniyetsizlikle taşınır; zorla kabul ettirilir ya da reddedilir"

Etniklik kavramı sosyal bilimlerde sanıldı̆̆ gibi eski bir kavram değildir. Bu kavram ilk olarak İngilizce literatürde David Riesman tarafından 1953'de kullanılmıştır. ${ }^{18}$ Sağır ve Akıllı'ya göre, 1935'de Lulian Huxley ve A. C. Haddon, 1rk, ulus ve kültür kavramlarının arasındaki büyük karmaşıklığa son vermek amacıyla grupları tanımlarken ırk kavramının yerine etnik grup veya halk kavramını kullanma yoluna gitmişlerdir. ${ }^{19}$ Wallerstein’e göre, ${ }^{20}$ "etnik grup" kavramı günümüzde “azınlık” kavramının yerini almıştır. Irkların genetik bir kategori olarak görünür fizikî biçime sahip

13 Dieter Langewiesche, Nation, Nationalismus, Nationalstaat in Deutschlandund und Europa, München: Beck, (2000), s.25; Abdulvahap Akıncı ve Oğuz Yavuzyılmaz, "Milli Kimlik İnşaasında Resmi Tarih Yazımının Rolü”, Turkish Studies, 13/30, (2018), s.20.

14 M. Naci Bostanc1,"Etnisite, Modernizm ve Milliyetçilik", Türkiye Günlüğü, 75 (2003), s.6.

15 Erol Kurubaş, "Etnik Sorunlar: Ulus-Devlet ve Etnik Gruplar Arasındaki Varoluşsal İlişki”, Doğu Batı, 11/44 (2008), s.13; Haldun Çancı, "Değişmeyen Boyutları Bağlamında Milliyetçiliğe Teorik ve Kavramsal Bir Bakış”, Süleyman Demirel Üniversitesi İİBF Dergisi, 13/2 (2008), s.108.

16 Kurubaş, "Etnik Sorunlar", s.13.

17 Gerd Baumann, Çokkültürlülük Bilmecesi: Ulusal, Etnik ve Dinsel Kimlikleri Yeniden Düşünmek, çev., Iş1 Demirakın, Ankara: Dost Kitabevi, 2006, s.65-66.

18 Süleymen Yıldız, "Kimlik ve Ulusal Kimlik Kavramlarının Toplumsal Niteliği”, Milli Folklor, 19/74 (2007), s.15.

19 Meral Öztoprak Sağır ve Serkan H. Akıllı, "Etnisite Kuramları ve Eleştirisi”, C. Ü. Sosyal Bilimler Dergisi, 28/1 (2004), s.4.

20 Immanuel Wallerstein, "Halklığın İnşası: Irkçlık, Milliyetçilik ve Etniklik", Irk, Ulus, Sınıf; Belirsiz Kimlikler, çev., Nazlı Ökten, İstanbul: Metis Yayınları, 1993, s.98. 
oldukları varsayılır. Irk kavramı farklı sosyal grup ve kategorileri içerecek bir şekilde kullanılabilmektedir. ${ }^{21}$ Son yüz elli yıllık süre içerisinde ırkların ayırt edici özellikleri ve isimlerine dönük olarak ciddî tartışmaların akademik dünyada yapıldığı gözlemlenmektedir. Bu tartışmalarda ulus, bir devletin sınırları ile örtüşen toplumsal-siyasî bir kategori olarak varsayılır. Etnik grupların devlet sınırlarına bağlı olmayan, kuşaktan kuşağa geçen bazı ortak özellikleri ve davranış kalıpları olan kültürel bir kategori olduğu varsayılır.

Bir grubun etnik grup olduğunu söyleyebilmek için o grubun kültür kalıbından diline, dinine, edebiyatına, musikisine, örf ve âdetlerine, müziğine ve sosyal hayatın bütün parçalarında toplumun geri kalanından farklı olması gerekmektedir. Etnik bir gruptan bahsetmek için, mahallî bir dile sahip olmaları yeterli bir ölçüt değildir. Aynı zamanda yaşama tarzlarında da farkın olması gerekir. Etnik grup ile alt kültür birbirinden farklıdırlar. Herhangi bir etnik grubun bir milletle özdeşleştirilmesi gerekmemektedir. ${ }^{22}$ Bu bakış açısı temel alındığında, kendini etnik grup olarak adlandıran birçok grubun, etnik grup özelliği taşımadığı söylenebilir.

Hiçbir zaman soy, kabile ve ırk saf olarak var olmadı. Her zaman bunlar karışıktı. Her yerde ulusal çoğunluklar tarafından yönetilen azınlıklar mevcuttu. En azından 1890'dan beri ırkçı doktrinler Avrupa sömürge politikalarının bir parçası haline geldi. Bu sayede Avrupa sömürgeciliğgi haklılaştırılmaya çalışıldı. Bu doktrinler Avrupa'da yaşayan azınlıklara tahakküm kurmak amacıyla da kullanıldı. ${ }^{23}$

Balibar’a göre, ${ }^{24}$ modern ırk kavramı, bir horgörme ve ayrımcılık söyleminde yer almaktadır ve insanlığı "alt-insanlık” ve "üst-insanlık” olarak bölmektedir. Bu kavram başlangıçta bir etnik ya da ulusal gösterime değil, bunların yerine bir sınıfsal gösterime işaret etmekteydi. Bu kavramda toplumsal eşitsizliklerin yaratılıştan geldiği anlayışı, tıpkı kast sisteminde olduğu gibi sunulmaktaydı. Bu durum birçok 1rkçllık tarihçisi tarafından belirtilmektedir.

Smith'e göre, etnisiteler farklı dönemlerde ve yerlerde M.Ö. üçüncü bin yılın başlarından beri görülmektedirler. ${ }^{25}$ Etnik toplulukların kendilerine ait olarak gördükleri toprakları vardır. Bu topraklarda ikamet ediyor da olabilirler veya başka bölgelerde yaşadıkları hâlde, bu topraklar belleklerinde de yer alabilir. Etnik grupların bir anavatanları, kutsal yerleşim yerleri veya coğrafî mekânlarının olması gerekmektedir. Farklı bölgelere dağılmış olsalar da, günün birinde dönebilecekleri bir vatandır burası. Etnik bir topluluğun vatanını değiştirmesi de mümkündür (Türker'de olduğu gibi). Bütün anavatanlarda kutsal olarak kabul edilen (bu dinî veya etnik olabilir) mekânlar vardır. Etnik grup, bir dış etmen dolayısıyla anavatanlarından ayrılmak zorunda kalmışsa, etnik grupla anavatan arasında hep bir bağ ya da özdeşlik kalır. Et-

21Abdulvahap Akıncı ve Oğuz Yavuzyılmaz, "Milliyetçilik, Irk-Irkçılık İlişkisi”, Turkish Studies, 13/26 (2018), s.78-79.

22 Mustafa E. Erkal, Sosyoloji (Toplumbilimi), İstanbul: Der Yayınları, 6. bs., 1995, s.32-33.

23 Siegfried Weichlein, Nationalbewegungen umd Nationalismus in Europa, 2. bs,, 2013, s.16.

24 Etienne Balibar, "Sınıf Irkçılığı", Irk, Ulus, Sınıf; Belirsiz Kimlikler, çev., Nazlı Ökten, İstanbul: Metis Yayınları, 1993, s.258.

25 Smith, Ulusların Etnik Kökeni, s.58. 
nisitelerin üyeleri arasında özellikle kötü zamanlarda güçlü bir aidiyet ve dayanışma duygusu oluşur. ${ }^{26}$ Ortak düşmanın varlığı, kendi varlıklarını tehlikeye attığı için, daha fazla dayanışma gerçekleşir.

Anavatan mitosu uzun yüzyıllar geçmiş olsa da devam eder. Füsun Üstel’e göre "vatan" kelimesinin semantik olarak üç farklı boyutundan söz etmek mümkündür: ${ }^{27}$

“Topraksal (teritoryal), kökensel (vatan tarihsel bir veridir; 'ataların bırakt1ğı'dır) ve son olarak kolektif/ulusal (ulusun mekânsal boyutu). Ancak milliyetçiliğin (özellikle de romantik Alman milliyetçiliği) duygusal boyutu, 'vatan'ı aşkın bir değer, mutlak ve o oranda kutsal bir ideal hâline getirir. Dolayısıyla 'vatan'la semantik ilişki içinde olan bütün kavramlar -başta vatanseverlik olmak üzere- duygu alanından ifade edilir: Vatan için fedakarlıkta bulunmak, vatan için savaşmak, vatan için ölmek.... Zira 'vatan' duygusal olarak bağlı olunan ülkedir, 'atalar'ın ülkesidir.”

Kurubaş’a göre, ${ }^{28}$ etnisite kavramına kuramsal olarak primordial ve araçsal olmak üzere iki şekilde yaklaşılmaktadır. Bu yaklaşımlardan primordial yaklaşıma göre, etnisite doğuştan edinilen, dünyaya geldiği yerden, din, dil, sosyal pratikler ve akrabalık ilişkilerinden elde edilen değiştirilemez bir bağlılık duygusuna neden olmaktadır ki bu durum aynı özellikleri taşıyan kişiler arasında yakın ilişkiler kurulmasını kolaylaştırır ve bu kişilerde dayanışma ortaya çıkar. Bu yolla etnisite ortaya çıkmış olmaktadır. Araçsalcı yaklaşım ise etnisitenin bir siyasî inşa eseri olduğunu, siyasî elitlerin bazı siyasî amaçları elde etmeye dönük olarak harekete geçirmek için kullandıkları bir araç olduğunu öne sürmektedirler. Etnik gruplarda 'biz’ olmayı sağlayan dil, din, kültür ve benzeri bazı ortak özelliklerin olmasının yanında, bireylerde de bu 'biz’e dönük bir aidiyet duygusu vardır. Diğer etnik grupların üyeleri ile olan ilişkilerde kendi farklılığını öne çıkaran ve diğer gruptan olanları ötekileştiren bir duyguya sahip olmaktadır. Etnik sınırların toplumsal olarak inşa edilmiş olduğu ve bu sınırların belli bir ölçüde geçirgen olduğu ve dolayısıyla etnik grupların değişmez olmadıkları söylenebilir.

Etnisite ile ulusu birbirine karıştırmamak gerekmektedir. Siyasî niteliği olmayan, ortak bir geçmişe sahip, kültürel, topraksal ve tarihî bağları olan etnik gruplar, ulus değildirler. Bunlar ulusun özelliklerinin bir bölümüne sahip değillerdir. Mesela etnisitede bir ülkeye dönük bağ, sembolik ve tarihî kalabildiği hâlde, ulusta bu bağ siyasî bir nitelik taşır ve bir gerçeklik olarak mevcut sınırlar ile bu sağlanmış olur. Kurubaş่a göre, ${ }^{29}$ etnik bir grubun kendi ülkesinde ikamet etmesi şart değildir. Ulusta bir iş bölümü, ekonomik birlik yani kamusal kültür, ortak yasal kurallar mevcutken, bu özellikler etnisitede mevcut değildir. Uluslar dışlayıcı değillerdir. Yani bir ulusa ait olmak için doğuştan bazı özelliklere sahip olmak genelde gerekmemektedir ama etnisitelerde bu tür özellikler aranmaktadır. Dolayısıyla etnik grupların bu özellikle-

26 Smith, Ulusların Etnik Kökeni, s.53-56; Anthony D. Smith, Milli Kimlik. çev., Bahadır Sina Şener, İstanbul: İletişim Yayınları, 4. bs., 2007, s.25-26.

27 Füsun Üstel, Makbul Vatandaş"in Peşinde, İstanbul: İletişim Yayınları, 4. bs., 2009, s.159.

28 Kurubaş, "Etnik Sorunlar", s.14.

29 Kurubaş, "Etnik Sorunlar”, s.14-15. 
riyle dışlayıcı oldukları söylenebilir.

Etnik grup ile ulus farklı olmakla beraber bunların birbirlerine çok benzedikleri de söylenebilir. Her ne kadar etnik gruplar arasındaki dayanışma duyguları onların ulus olmalarını sağlamasa da, potansiyel uluslar olarak etnik grupları görmek doğru olur. Çünkü belli şartlar altında etnik grupların ulus hâline gelebildiklerini tarih göstermektedir. Siyasileşen etnik gruplar milliyetçilik ideolojisi doğrultusunda hareket etmektedirler. Etnik grupların ulus hâline geldiklerinde etnik özelliklerinin olduğu gibi kaldığı söylenemez. Zaman içerisinde değişime uğramaktadırlar. Bu özellikler, yeni şartlara uygun olarak yeniden üretilmeleri durumunda varlıklarını devam ettirebilmektedirler. Smith’e göre bütün uluslar bir "etnik çekirdek temelinde doğmaktadırlar. Tarihin her döneminde farklı coğrafyalarda etnik topluluklar vardı. Birçok ulus ve milliyetçilik daha önceden mevcut olan etnisiteyi ve bunların etnomerkeziyetçiliğini temel alarak ortaya çıkmıştır. Modern uluslar her ne kadar modern öncesi etnik grupların farklı özelliklerini taşıyorlarsa ve modern dönemin başlarına kadar mevcudiyetini muhafaza etmiş olan etnik topluluklara çok şey borçlu olsa da, milliyetçiliğin bir hareket ve ideoloji olarak tamamen modern bir olgu olduğu söylenebilir. ${ }^{30}$ Smith'in geliştirmiş olduğu yatay ve dikey etni ayrımı, bir taraftan etnik çatışma ve etnik devamlılı̆̆ı, diğer taraftan da değişik ulus modellerinin ortaya çıkışının anlaşılmasında açıklayıcı olmaktadır. Smithe göre batılı ulusların önemli bir bölümü yatay-bürokratik etni çeşidine dayanmaktadırlar. Bu tür etni tipinde etnik oluşumlar daha ziyade üst tabaka ile sınırlıdır. Çevrelerinde bulunan komşu yatay etnilerin üst tabakaları ile sıkı bağlar oluşturarak coğrafî olarak yayılmıştır. Bundan dolayı yatay etniler yoluyla oluşmuş olan uluslar teritoryal yönden daha kapsayıcı bir özellik sergilerler. Dikey-demotik (etnik öze dayalı) etni tipini ise Batılı olmayan ulusların büyük kısmında görmek mümkündür. Bu tip, yatay etni tipine oranla daha yoğun ve popülerdir. Dikey etni modeli toplumdaki bütün tabaka ve sınıflara yayılmaya çalışmaktadır. Bütün farklı toplumsal tabakaların birlikteliğini sağlamaya dönük olarak diğer uluslardan ayırt edici bir tarihî kültür mevcuttur. Bu model daha dışlayıcıdır. ${ }^{31}$

Bostancı, etnisite ile milliyetçiliğin inşa niteliği arasındaki ilişkinin üzerinde durmaktadır:" "Milliyetçiliğin inşa niteliği, onun birden icat edilmesi değil etnik bilincin mevcut siyasal coğrafya da dikkate alınarak bir millet tahayyülü olarak yeniden üretilmesi manasındadır."

Etnik sorunların nedenlerini Michael E. Brown üç düzeyde açıklamaktadır: Sistem düzeyi, ulusal düzey ve algısal düzey. Sistem düzeyinde etnik sorunun ortaya çıkış1nı açıklayan kuramsal çalışmalar daha ziyade güvenlik sistemleri ile durumu açıklamaktadır. Bu durum, etkin bir merkezî devletin bulunmadığı durumlarda ortaya çıkar. Böyle durumlarda etnik gruplar, kendilerine komşu etnik gruplardan gelebilecek tehditlerden hareketle kendi güvenliğini sağlamaya dönük girişimlerde bulunurlar. Diğer etnik gruplarda aynı yaklaşımla hareket edeceklerdir ve ortaya bir kısır döngü çıkacaktır ki bu duruma "güvenlik ikilemi” denilmektedir. Barry R. Pose bu

30 Smith, Uluslarm Etnik Kökeni, s.40-41.

31 Smith, Ulusların Etnik Kökeni, s.113-125

32 Bostanc1, “Etnisite, Modernizm”, s.15. 
durumun daha ziyade imparatorlukların çöktüğü durumlarda gerçekleştiğini, kendi güvenlik kaygısı ile hareket eden etnik grupların kendi içlerine kapandıklarını ve bu yolla kendilerine etnik coğrafya oluşturmaya çalıştıklarını, bunun önünde engel olarak gördükleri diğer etnik gruplara karşı harekete geçtiklerini belirtmektedir. Brown'un sözünü ettiği ulusal düzeydeki açıklamalar ise devletin demokratikleşme derecesi, etkinliği ve uygulanan ulusçuluğun etnik gruplar arasındaki ilişkilere olan etkisi çerçevesindedir. Bu açıdan bakılarak yapılan açıklamalar, devletin ekonomik kalkınmadaki ve kamu güvenliğini sağlamadaki yetersizliklerinin etnik ulusçulukların gerekçesi olduğunu ileri sürmektedir. Etnik temelde ortaya konulan ulusçuluk uygulamaları diğer etnik gruplarda da aynı tarz duyguların ortaya çıkmasına ve çatışma ortamının doğmasına neden olacaktır. Etnik grupların sözlü tarihlerinde dile getirilen bazı sorunlar, diğer bazı gruplara karşı önyargının oluşmasına ve çatışmaya neden olabilir ki, bu algısal düzeyde etnik sorunların çıktığına dönük kuramsal çalışmalar tarafından ileri sürülmektedir. ${ }^{33}$

Etnik grupların siyasileşerek bazı taleplerde bulunmalarının tarihî, kültürel, dinî, psikolojik, ekonomik, sosyal bazı nedenleri olsa dahi, bunun asıl gerekçesi ulus inşa sürecinde ve ulusçuluğun doğasında aranmalıdır. Etnik sorunların ortaya çık1ş1, ulus-devlet olgusu ile birlikte söz konusu olmuştur. Ulus-devletler, sinırları belli topraklar üzerinde yaşayan farklı grupları ve onlara ait olan kimlikleri tekleştirmek için farklı yöntemlere başvurur. Bunun için gerek gördüğünde bir etnik grubun geleneklerini canlandırırken, gerek gördüğünde de geleneği bizzat icat eder. ${ }^{34}$ Smith'e göre, ${ }^{35}$ bugün kökleri çok eskilerde yattığı sanılan birçok gelenek aslında sonradan icat edilmişlerdir. Mesela İskoç eteği ve kumaşı 19. yüzyılın ortasında II. James tarafından icat edilmiştir. İngiltere’deki taç giyme geleneği 19. yüzyıla aittir. Eski motifler bir araya getirilmiştir. Modern ihtiyaçlara dönük olarak geliştirilmiştir.

Prys Morgan, makalesinde, ${ }^{36} \mathrm{Gal}$ kimliğinin inşasındaki araçları ayrıntılı olarak analiz etmeye çalışmıştır. Bu çalışmada Gal millî kimliğinin inşasında geleneklerin nasıl inşa edildiği ortaya konmaktadır. Özellikle aydınların gelenek inşasında belirleyici rolleri dikkat çekmektedir.

Giddens’a göre, ${ }^{37}$ bugün İskoçların geleneksel elbisesi olarak bilinen eteklikler aslında 18. yüzyılda bir İngiliz sanayici olan Thomas Rawlinson tarafından icat edildiği sanılmaktadır. Rawlinson'un gayesi giyim tarzını çalışanlar için daha uygun hale getirmekti. Bu icadın gayesi geleneği korumak değil tam aksiydi.

Highland'a ait bağımsız bir gelenek mevcut değildi. 18. yüzyılın sonunda ve 19. yüzyılın başında bağımsız bir Highland geleneği icat edildi ve bütün İskoçyàya dayatıldı. Bu süreç, üç aşamada gerçekleştirildi. Önce İrlanda'ya karşı kültürel yönden isyan edildi ve bu çerçevede eski İskoçya tarihi yeniden yazıldı (uyduruldu). Bu

33 Kurubaş, "Etnik Sorunlar", s.17.

34 Kurubaş, "Etnik Sorunlar", s.22.

35 Smith, Ulusların Etnik Kökeni, s.228.

36 Prys Morgan, "Bir Ölümden Bir Bakışa: Romantik Dönemde Gal Geçmişinin Peşinde”, Geleneğin İcadı, haz., Eric Hobsbawm ve Terence Ranger, çev., Mehmet Murat Şahin, İstanbul: Agora Kitaplı̆̆ı, 2006, s.51-118.

37 Anthony Giddens, Elimizden Kaçıp Giden Dünya, çev., Osman Akınhay, İstanbul: ALFA, 2000, s.51. 
tarih yazımında İrlanda’nın İskoçya’nın kültürel müstemlekesi olduğu iddiası dile getirildi (gerçeğin tam tersi bir yaklaşım). İkinci aşamada Highland'ın ilksel gelenekleri olarak sunulan gelenekler, suni olarak yaratıldı. Üçüncü olarak bu yaratılmış olan gelenekler, Lowland İskoçya’sına Normanların, Saksonların ve Piktlerin Doğu İskoçyası'na sunuldu ve bu topluluklar tarafından benimsenmeleri sağlandı ${ }^{38}$ Çarpıc1 bir örnek de Hindistan’dan verilebilir. 1860 öncesi dönemde İngiliz ve Hintli askerler aynı tarzda giyinmekteydiler. Ama kendi farklılıklarını ortaya koymak amacıyla yani Hintlileri, Hintli olarak, görünüş olarak da ayrıştırmak istediklerinden, üniformalarına otantik bazı eklentiler yapıldı (kuşak, sarık ve tunik). Yapılan bu icadın bir bölümü sonraki kuşaklar tarafından da kabul gördü ve geleneksel Hint askeri elbisesi olarak günümüzde dahi kabul görmektedir.

Bir şeyin gelenek hâline gelmesi için uzun zaman geçmesi gerekmemektedir. İngiltere'de monarkın Noel konuşmasının her yıl yayınlanması bir gelenek hâline gelmiş olduğu hâlde bu olay ilk kez 1932'de gerçekleşmiştir. ${ }^{39}$ Her ulus devletin bu tarz gelenekleri inşa ettiği görülmektedir.

Avrupalıların ve bazı Afrikalıların "modernleştirici” amaçlar doğrultusunda birleşmelerini ve birlikte hareket etmelerini kolaylaştırmak amacıyla, Avrupa'da 19. yüzyılda icat edilmiş olan gelenekler Afrika'ya sokulmuştur. ${ }^{40}$ Gerçi Afrika'ya sokulan geleneklerin büyük bir bölümü, buradaki halkların kaynaşmasından ziyade, ayrışmasına katkı sağlamıştır.

Şimdiki kullanımıyla gelenek terimi son iki yüzyılın ürünü olarak ortaya çıkmıştır. Ortaçağda her yerde gelenekler hâkim olduğu için böyle bir kelimeye ihtiyaç yoktu. Gelenek kelimesinin kendisi de modern çağın icatlarından biridir. Aydınlanma filozofları geleneği cehalet ve dogma ile özdeşleştirerek kendi yaklaşımlarının doğruluğunu ispatlamaya çalışmışlardır. Hobsbawm ve Ranger derledikleri kitaba "Geleneğin İcadı” ismini verdiler. İki çeşit gelenek olduğunu, bir bölümünün kökleri eskiye dayanan gerçek gelenekler, diğerlerinin ise icat edilmiş gelenekler olduğunu ileri sürüyorlar. Onlara göre icat edilmiş gelenekleri gerçek geleneklerden ayırmak gerekir. Çünkü bunların kökleri eskiye dayanmazlar ve tasarlanarak, iktidar aracı olarak kullanıma sunulmuşlardır. Giddens’a göre ise bütün gelenekler icat edilmişlerdir. Gelenekler bilinçli veya bilinçsiz olarak oluşturulabilirler ama her halükarda iktidarla iç içe bir konumdadırlar. Egemen sınıfların (kral, rahip, vb.) kendi konumlarının devamını sağlamaya dönük olarak modern öncesi toplumlarda da kullandıkları icat edilmiş olan gelenekleri vardı. Geleneklerde zaman içerisinde değişime uğrarlar. Bunlar çok yavaş değişebildikleri gibi, ani değişimler de gerçekleşebiliyor. Yapılan, icat edilen geleneklerin zaman içerisinde yeniden icat edilmesidir. Geleneklerde ritüeller ve tekrarlar ayırt edici özelliklerdir. Gelenekler bir çeşit gerçeği belirleme özelliğiyle dikkat çekmektedirler. Bir eylem geleneklere uygun olduğunda, başka

38 Hugh Trevor-Roper, “Geleneğin İcadı: İskoçya’nın Hıghland Geleneği”, Geleneğin İcadı, haz., EricHobsbawm ve Terence Ranger, çev., Mehmet Murat Şahin, İstanbul: Agora Kitaplığı, 2006, s.21.

39 Giddens, Elimizden Kaçıp Giden Dünya, s.52-55.

40 Terence Ranger, “Sömürge Dönemi Afrika’sında Geleneğin İcadı”, Geleneğin İcadı, haz., Eric Hobsbawm ve Terence Ranger, çev., Mehmet Murat Şahin, İstanbul: Agora Kitaplığı, 2006, s.287. 
bir meşrulaştırmaya ihtiyaç duyulmadan gerçekleştirilir. Sorgulanmadan uyulan bir çerçeveyi bizlere gelenekler sunmaktadırlar. ${ }^{41}$ Modern devletin vatandaştan beklediği tavırların sağlanması açısından, ulus devletin temel değerlerinin gelenek haline getirilmesi gerekmektedir.

Geleneklerin icat edilmeleri ile yapılan şey, geçmişe atıfta bulunularak rutinleştirme ve formelleştirmeyi sağlamaktır. Millî marşlar ve ulusal bayraklar da icat edilmişlerdir. Hobsbawm’a göre eski dönemlere ait olan malzemeler yeni türde icat edilen geleneklerin inşasında kullanılmaktadırlar. Mesela alışıla gelmiş olan geleneksel pratikler (nişancılık, halk şarkıları vb) günün ulusal amaçlarına uygun hâle getirilmekte ve ritüelleştirilerek kurumsallaştırılmaktadırlar. Geleneksel halk şarkıları okullarda ögrretilirken bunların benzerleri ulusal içeriklerle dolu olarak üretilmekte ve öğrencilere aktarılmaktadır. Düzenlenen festivallerde de millî semboller aşılanmaktadır. İcat edilmiş olan gelenekler ile nispeten yakın tarihlere ait olgular olan ulus, ulus-devlet, ulusal tarihler ve semboller, yakın bir bağlantı içerisindedir. ${ }^{42}$

Hobsbawm’a göre, ${ }^{43}$ geleneklerin seri olarak üretilmeleri I. Dünya Savaşı’ndan 30-40 yıl öncesine rastlamaktadır. Bu seri üretim hem resmî hem de gayri resmî alanda gerçekleşmiştir. Yeni olan veya dramatik bir şekilde dönüşüme uğramış olan toplumsal grupların ve çevrelerin arasındaki ilişkileri düzenlemek, kimliklerini ifade etmek ve kendi aralarındaki ilişkileri düzenlemek amacıyla yeni araçlara ihtiyaç duyulmuştur. $\mathrm{Bu}$ tür değişim hâlindeki toplumları geleneksel tarzda yönetmek de artık imkânsız hâle gelmişti. Bütün bu amaçlar doğrultusunda bilinçli bir çaba sonucunda özellikle siyasî gelenekler icat edilmişlerdir. Devletler bu bağlamda vatandaşların faaliyet alanlarını gittikçe daha fazla tanımlamaya ve kayıt altına almaya başladılar. Yönetimde ve hukukta standartlaştırmalara gidildi ve ülke sınırlarında yaşayan insanlar birer 'vatandaş' hâline getirildiler. Bireylerin ulusal sınırlar dâhilinde bilinçlenmeleri sağlandı. En basitinden işçiler, ülke sınırları çerçevesinde örgütlenmelere gittiler ve bu çerçevedeki yani ulusal sınırlar dâhilindeki siyasî hareketlerle kendilerini özdeşleştirdiler. Bu dönemlerde icat edilmiş olan en evrensel gelenekler (siyasî), devletler tarafından meydana getirilmiş olan geleneklerdi.

Bütün toplumu tek bir ulus çatısı altında bütünleştirmek için başvurulan yöntemler beraberinde etnik sorunları getirmektedir. Ulus-devlete ait bazı kurgular etnik sorunların doğmasına neden olabilir. Ulusu meydana getiren insanların aynı kültürden (bazen de aynı soydan) olması gerektiği düşüncesi ve bu düşünceyi bir gerçeklik hâline getirmek için devletin yaptığı faaliyetler sonucunda devletin belirlemiş olduğu tekil ulusal kimliği tanımasını ve ona sadakat göstermesini talep etmesi en belirleyici nedendir. ${ }^{44}$ Devletlerin yurttaş veya etnik ulus modeline dayanması bu gerçeği değiştirmemektedir. Nitekim Kymlicka vermiş olduğu ABD örneğinde, ${ }^{45}$ bu durumu

41 Giddens, Elimizden Kaçıp Giden Dünya, s.53-55.

42 Eric Hobsbawm, “Giriş: Gelenekleri İcat Etmek”, Geleneğin İcadı, haz., Eric Hobsbawm ve Terence Ranger, çev., Mehmet Murat Şahin, İstanbul: Agora Kitaplığı, 2006, s.5-17.

43 Eric Hobsbawm, "Seri Üretim Gelenekler: Avrupa, 1870-1914", Geleneğin İcadı, haz., Eric Hobsbawm ve Terence Ranger, çev., Mehmet Murat Şahin, İstanbul: Agora Kitaplı̆̆ı, 2006, s.305-307, 328.

44 Kurubaş, "Etnik Sorunlar", s.22.

45 Will Kymlicka, Çokkültürlü Yurttaşlık/ Azınlık Haklarının Liberal Teorisi, çev., Abdullah Yılmaz, İstanbul: 
yalın bir şekilde ortaya koymaktadır. Böyle yurttaş ulus niteliği hiç tartışmasız ortada duran bir ülkede bile hükümet, ortak bir kültür ve dili teşvik etmekte ve dolayısıyla taraf olmaktadir.

Smith'e göre, ${ }^{46}$ çok etnikli devletlerde ikilik ve istikrarsızlık vardır. Çok etnikli devletlerde tek bir etnik grubun egemenliğinin olduğu gözlemlenmektedir. Böyle devletlerde daha küçük olan etnik grupları kapsamaya veya etkilemeye çabalayan bir etnik grubun hâkimiyeti söz konusudur. Göçmenlerden oluşan ABD’de bile bir etnik topluluk hâkimdir ve diğerlerini şekillendirmeye çalışmaktadır.

Modern devletlerde ortaya çıkan bölünmeyi en iyi dile getiren Disraelidir. Ona göre bu devletlerde asıl sorun, tek bir toplumsal oluşum olarak kendilerini sundukları hâlde, realitede 'iki ulus'a bölünmüş olmasıydı. Yani bu toplumlarda bir taraftan çok zengin bir sınıf varken, diğer taraftan geniş kesimler yoksulluk içerisinde yaşamaktaydı. Bunu sınıf ırkçılığı olarak adlandırmak mümkündür. Balibar’a göre, sınıf 1rkçılığı ile etnik ırkçılık arasında karşılıklı bir belirlenim mevcuttur. ${ }^{47}$

Ulusçuluğun temel ilkesi konumunda olan 'egemenlik ulusundur' söylemi, aslında mevcut iktidar ilişkilerinin meşrulaştırılması amacını gütmektedir. Burada amaç, yeni oluşan grupların ve sınıfların iktidardan belli bir oranda pay almalarının önünü açmaktır. Yeni durumu meşrulaştırmak amacıyla resim, heykel vb. sembolik icatlardan faydalanma yoluna gidilmektedir. Bu yolla rejimin halk kesimlerince kutsallaştırılmasının sağlanması amaçlanmaktadır. Törenler, ayinler ve sembollerin icadı ile zor kullanılmasına gerek kalmaksızın insanların belli bir dünya görüşünü kabullenmeleri ve mevcut siyasî yapıya sadakat göstermelerinin sağlanması amaçlanır. ${ }^{48}$ Bazı durumlarda bu ritüellerin yerleşmesi için yaptırımlara da başvurulabilmektedir.

Ulus-devletler, milliyetçilik ideolojisi ve hukuk, askerlik ve en önemlisi eğitim gibi uluslaştırma araçlarından faydalanarak, asimilasyon politikasını uygulayarak, ulus inşasını gerçekleştirirler. Ulus-devlet, bu süreçte bireylerin herhangi bir başka gruba değil, ulus-devlete sadakatin gerçekleşmesini amaçlarlar. Bu yolla ulusal kimliğin gelişmesi amaçlanır. Ulus inşası sürecinde her şeyden önce bağımsızlık garantiye alındıktan sonra meşruluk kazanmış bir ulusal yönetimin oluşturulması, kültürel standartlaştırma işleminin tamamlanması, siyasî vatandaşlık anlayışının yerleşmesi ve zenginliklerin yeniden dağıtılması sağlanmaya çalışılır. Eğitim yoluyla ulus bilinci, askerlik yoluyla vatan bilinci ve siyasî katılma ile de vatandaşlık bilinci aşılanmaya çalışılır. Bu süreç içerisinde millî marş, bayrak, haritalar, heykeller vb. ulusal övünmeyi getirecek sembolik üretimlerde bulunulur. Ayrıca ülkede bulunan farklı diller, gelenekler gibi yerel değerler ulusal potada eritilir veya marjinalleştirilerek etkisizleştirilmeye çalışılır. ${ }^{49}$ Burada devreye entegrasyon adı altında asimilasyon politikaları girmeye başlar.

Ayrıntı Yayınları, 1998, s.178-181.

46 Smith, Uluslarm Etnik Kökeni, s.196.

47 Balibar, "Sınıf Irkçılı̆̆ı", s.262-268.

48 N. Durak Aksoy ve H. Adnan Arslantaş, "Modern Bir İdeoloji: Ulusçuluk”, Hikmet Yurdu, 2/3 (2009), s.229.

49 Kurubaş, "Etnik Sorunlar”, s.23. 
Ulusal inşa sürecinin entegrasyon, kültürel çoğulculuk veya asimilasyon yöntemiyle yapılıyor olması, sonucu değiştirmez. Asıl olan asimilasyondur. Bunun en iyi sloganlaşmış söylemi ise 'tek devlet, tek millet ve tek dil'dir. Bu söylemde amaçlananın aslında azınlığın ulusal kimlik içerisinde eritilmesi olduğu görülmektedir. Bu süreç işletilirken sanayileşmenin getirdiği sosyal hareketlilikten de faydalanılır. Ayrıca tek bir dilin kullanılması ve diğer dillerin kullanılmaması için gerekli yasal düzenlemeler yapılır. Bu süreçte eğitimin ve basın-yayının önemi belirgindir. ${ }^{50}$ Aynı devlet s1nırları içerisinde yaşayan insanların aynı dili konuşmaları olgusu, ulus-devletleşme sürecinde ortaya çıkmıştır. Eski imparatorluklarda farklı dilleri konuşan topluluklar yan yana yaşamaktaydı. ${ }^{51}$ Ulus devletlerde vatandaşların duygusal bağlılığını sağlamasında en önemli etken haline gelmiştir ortak dil.

Modern ulus devletlerin inşası ile ortaya çıkmış olan milletlerin geçmişine bakılacak olursa, bu toplumların tarihin hiçbir döneminde homojen olmadığını görecektir. ${ }^{52}$ Etnik varlıktan yola çıkılarak siyasileşme olgusu ulus-devletleşme süreci ile birlikte kendini göstermiştir. Ulus-devletlerin kendilerine temel aldıkları etnik varlık, kendi sınırlarını ulus-devletin sınırlarına genişletme yoluna gitmiştir. Bütün çabalara rağmen dünyada etniklik ile ulusal sınırların örtüşmesi anlamında bir sonuç elde edilememiştir. Etniklik aslında dinamik bir süreçtir ve tarihî köklere dayanmasına rağmen zaman içerisinde yeni etnik varlıklar, ortaya çıkabilmektedir. Bazı etnik grupların birleşmesi sonucu yeni bir etnik varlık da ortaya çıkabilir veya bunlardan biri diğerlerini asimile edebilir. ${ }^{53}$ Ulusların etnik temelleri ile ilgili Balibar şu yaklaşımı savunmaktadır: ${ }^{54}$

"Hiçbir ulusun doğal olarak etnik temeli yoktur fakat toplumsal oluşumlar ulusallaştıkça içerdikleri, paylaştıkları ya da hükmettikleri topluluklar da "etnikleşir” yani sanki kendiliğinden bir ilk kimliğe kültüre çıkarlara sahip olan, bireyleri ve toplumsal koşulları aşan doğal bir cemaat oluştururmuşçasına geçmişte ya da gelecekte temsil edilir hâle gelir.”

Wallerstein'e göre, ${ }^{55}$ çağdaş dünyadaki tek uluslararası statü grubu kategorisi 'irk'tır. Eskiden din bu işlevi görmekteydi. Statü grubundaki sıralamada hangi yerde olunduğunu belirleyen faktör renkten çok sıralamadır. Nitekim Québec'deki ayrılıkçılar, kendilerini "beyaz zenciler" olarak adlandırmaktadırlar.

Özellikle Soğuk Savaş’ın sona ermesinden sonra ekonomik kalkınma ve ulusal bütünleşmenin modernleştirici etkisi nedeniyle etnik kimliklerin etkisinin azalaca-

50 Kurubaș, “Etnik Sorunlar”, s.23-24.

51 Etienne Balibar, "Ulus Biçimi: Tarih ve İdeoloji”, Irk, Ulus, Sınıf; Belirsiz Kimlikler, çev., Nazlı Ökten, İstanbul: Metis Yayınlar1, 1993, s.123.

52 Bärbel Völkel, "Nationalismus - Ethnizismus - Rassismus? Fremde Blicke auf den genetisch-chronologischen Geschichtsunterricht”, Historisches Lernen als Rassismuskritik, Hrsg: Christina Isabel Brüning, Lars Deile, Martin Lücke, Schwalbach: Wochenschau Verlag, 2016, s.52.

53 Y1ldız, "Kimlik ve Ulusal Kimlik", s.15.

54 Balibar, "Ulus Biçimi: Tarih ve İdeoloji”, s.121.

55 Immanuel Wallerstein, "Bağımsızlık Sonrası Siyah Afrika’da Toplumsal Çatışma: Yeniden Değerlendirilen Irk ve Statü Grubu Kavramları”, Irk, Ulus, Sınıf; Belirsiz Kimlikler, çev., Nazlı Ökten, İstanbul: Metis Yayınları, 1993, s.252. 
ğ beklentisi hâkimdi. Fakat kısa zaman içerisinde meydana gelen gelişmeler, etnik kimliklerin zayıflamak yerine daha da güçlü bir şekilde ortaya çıktığını göstermiştir.

Almanya'da hızla artan ırkçılık, kendine siyasal alanda da her geçen gün daha fazla yer edinmektedir. Irkçı parti "Alternative für Deutschland” (AfD; Almanya için Alternatif) toplumsal olarak daha fazla kabul görmeye başladı. AfD açık bir şekilde İslam’ın Almanya'ya ait olmadığının altını çizmekle yetinmemektedir. AfD’ye göre, çokkültürlülük ideolojisi, Alman milletinin kültürel birliği ve sosyal barışının önündeki en büyük tehdittir. ${ }^{56}$

Dünyanın birçok bölgesinde etnik temelli çatışmalar yaşanmaktadır. Bu çatışma ortamının sadece gelişmiş veya gelişmekte olan ülkelerde (Malezya/Çinli, Nijerya/ Yoruba/Hausa/Ibo, Sri Lanka/Tamil, Gürcistan/Abhazya/ Acar, Irak/Kürt vb.) değil aynı zamanda dünyanın gelişmiş ülkelerinde de (İspanya/Katalan/Bask, İngiltere/ Kuzey İrlanda/İskoç, Kanada/Quebec, Belçika/Flaman/Valon vb.) kendini gösterdiği görülmektedir. Etnik temelli çatışmalar, dünya çapında bir olgu hâline gelmiştir. ${ }^{57}$ Fuller'e göre etnisite konusuna bakış açısı, Amerika'da önemli ölçüde değişime uğramıştır: ${ }^{8}$

“Türdeş yeni Amerikalıyı yaratırken çok-köklülüğü büyük ölçüde görmezlikten gelen eski etnik pota, şimdi her zamankinden daha etnik bilinçli bir topluma yerini bırakmaktadır. Bireysel etnik gruplara daha duyarlı, Amerika’nın nimetlerinin ülkenin bileşimindeki etnik öğelere bölüştürülmesi konusunda daha 'sayısal bilinçli' olduk.”

Etnik sorunlar demokrasinin yerleşmemesi, ülkenin gelişmemiş olması veya ulusal bütünleşmenin gerektiği ölçüde gerçekleştirilememiş olmasının etnik çatışmaların gerekçeleri olduğu söylenemez. Çünkü demokrasi ve insan hakları alanında ilerlemiş olan, refah seviyesi gelişmiş olan ülkelerde de etnik çatışmaların mevcudiyeti söz konusudur. Kurubaşa göre, ${ }^{59}$ her etnik çatışmanın kendine özgü iç dinamikleri olduğu söylenebilir. Her şeye rağmen demokrasi açığı, ulusal bütünleşmenin sağlanamamış olması ve ekonomik geri kalmışlık, etnik çatışmalar için ortamın daha uygun hâle gelmesi açısından etkili olabilmektedirler. Etnik sorunlar, mevcut siyasî sisteme yönelik şiddeti de içeren bir nitelik kazandığı durumda, diğer devletlerin de müdahil oldukları uluslararası bir sorun hâline gelebilmektedir. Etnik sorunların ulusçuluk, ulusal kimlik ve kendi kaderini belirleme çerçevesinde meydana gelmesi dolayısıyla, ulus-devletin varoluş felsefesi sorgulanmaktadır.

Özellikle postmodern dönemle ilgili tartışmaların olanca gücüyle yapıldı̆̆ı bir dünyayla karşı karşıyayız. Modernizmin temel ilkeleri ve kalıpları en ağır saldırılara maruz kalmaktadır. İnsanları ortak çıkarlar bağlamında bütünleştirmek pek müm-

56 Svenja Lückerath, "Völkischer Nationalismus auf dem Vormarsch; Das Nationverstaendnisdes Front Nation und der Alternative für Deutschland im Vergleich”, İnstitut für Politische Wissenschaft Selected Student Paper 68, Aachen, 2018, s.3.

57 Kurubaş, "Etnik Sorunlar", s.11.

58 Graham E. Fuller, Demokrasi Tuzağı, çev., Meral Gaspıralı, İstanbul: Altın Kitaplar Basımevi, 1996, s.161162.

59 Kurubaş, "Etnik Sorunlar”, s.12. 
kün gözükmemektedir. İnsanların bağlllıklarını soyut bir toplum idealinde gerçekleştirmeleri pek mümkün gözükmemektedir. Bunun yerine insanların bağlllıkları ve ahlaki sorumlulukları, tarihî olarak bağlı bulundukları topluluklara olacaktır. Küreselleşme bir taraftan dünya milletlerini birbirine yakınlaştırmıştır. Bunda en belirleyici olan ise iletişim alanındaki muazzam gelişmelerdir. Bir taraftan da ulus-devletler etnik talepler doğrultusunda sıkıştırılmaktadır. Ulus-devletlerin meşruiyet temelleri çatırdamaktadır. Postmodern yaklaşımlarla hayat sahasına kavuşan kültürel çoğulculuk yönündeki taleplerin demokrasi içerisinde bir çözüme kavuşmasının yolunu radikal demokrasi anlayışı sunmaktadır. ${ }^{60}$ Azınlıklar kendilerine yaşam alanı bulduklarında, içinde bulundukları toplumla daha uyumlu hareket edebilirler.

\section{Sonuç}

Milliyetçilik günümüzün yükselen değerlerinden biri olma özelliğini taşımaktadır. Dünyanın farklı yerlerinde irkçı saldırıların her gün arttığı ve giderek daha tehlikeli bir noktaya doğru evrildiği söylenebilir. Milliyetçiliğin ve milletlerin doğasını ve kökenini ortaya koyarak, bu sorunlarla nasıl baş edilebilir sorusunun cevabının aranması gerekmektedir.

Milliyetçiliğin kökenlerinin eski çağlara kadar gittiği ve doğal olgular olduğu yönündeki yaklaşım gerçekçi değildir. Bugünkü anlamda milletlerin ortaya çıkmasının çok daha geç bir döneme denk geldiği söylenebilir. Sanayi devrimi, şehirleşme, laiklik, güçlü merkezi devletlerin ortaya çıması gibi etmenler, milletleri inşa edilmesinde etkili oldular.

Modern anlamda milletlerin geç bir dönemde ortaya çımış olması, etnik kökenlerin bu millet inşalarında kolaylaştırıcı olarak önemli fonksiyon gördükleri gerçeğini görmeyi engellememelidir. Etnik köken benzerliği olan merkezi devletlerin kendi milletlerini inşa etmesi nispeten kolay olmuştur. Hâlbuki etnik bilincini korumuş olan farklı yapıların birlikte yaşadıkları devletlerde, uluslaşma süreci çok daha uzun zaman almıştır.

Bazı azınlıklar mevcut ulus devletin kendilerine biçmiş olduğu rolü benimsemekte ve fazla direnç göstermemektedir. Bu durumlarda, ulusun parçası olarak kaynaşma sağlanmakta ve zamanla bu azınlıklar yok olmaktadır.

Ulus devletlerin dayattığg resmi dil, ülkedeki farklı dillerin zamanla tarih sahnesinden silinmesine neden olabilmektedir. Kendi dilini kullanmakta ssrar eden etnik topluluklara baskı yapılabilmektedir.

Modern devletin inşa etmek istediği milletin bir parçası olmamak için direnen etnik topluluklara karşı entegrasyon söylemi altında, asimilasyon politikaları uygulanabilmektedir. Bazen baskının boyutu katliamlara kadar varmaktadır.

Küreselleşme, bir taraftan dünyayı küçük bir köy haline getirmekle beraber, diğer taraftan da farklılıkların kendini daha fazla ön plana çıkarmasına firsat vermektedir.

60 Nedret Çağlar, “Postmodern Anlayışta Siyaset ve Kimlik”, Süleyman Demirel Üniversitesi İİBF Dergisi, 13/3 (2008), s.381-382. 
Küreselleşme beraberinde yerelleşmeyi getirmektedir. Farklı kimliklerin kendilerine kamusal alanda yer bulmak için mücadele ediyorlar. Artık homojen bir toplum inşasını öngören bir kimlik inşası mümkün olamayacaktır. Her ne kadar farklılıklara karşı hoşgörüsüzlük hızla yükselse de, toplumların içinde ortaya çıkan yeni gruplar ve onların farklı yaşam tarzı talepleri, tek milletin inşasını imkânsızlaştırmaktadır.

Modern devletlerin ve milletlerin inşasının olmazsa olmazı olmayan etnik köken birlikteliği, sürecin sağlıklı ve başarılı işlemesi açısından oldukça önemlidir. Etnik olarak ortak bir geçmişe sahip olan topluluklardan modern ulus inşa etme girişimleri çok daha kısa sürede ve başarı ile sonuçlanabilmektedir.

\section{Kaynakça}

Akıncı, Abdulvahap. "Modern Ulus Devletlerin Doğuşu”. Dumlupınar Üniversitesi Sosyal Bilimler Dergisi. 34 (2012): 61-70.

Akıncı, Abdulvahap. “Milliyetçilik Kuramları”. C. Ü. İktisadi ve İdari Bilimler Dergisi. 15/1 (2014): 131-150.

Akıncı, Abdulvahap ve Oğuz Yavuzyılmaz. "Milliyetçilik, Irk-Irkçılık İlişkisi”. Turkish Studies. 13/26 (2018): 75-84.

Akıncı, Abdulvahap ve Oğuz Yavuzyılmaz. "Milli Kimlik İnşaasında Resmi Tarih Yazımının Rolü”. Turkish Studies. 13/30 (2018): 15-24.

Aksoy, N. Durak ve H. Adnan Arslantaş. "Modern Bir İdeoloji: Ulusçuluk”. Hikmet Yurdu. 2/3 (2009): 227-234.

Anderson, Benedict. Hayali Cemaatler; Milliyetçiliğin Kökenleri ve Yayılması. Çev., İskender Savaşır. İstanbul: Metis Yayınları, 2. bs., 1995.

Balibar, Etienne. “Ulus Biçimi: Tarih ve İdeoloji”. Irk, Ulus, Sınıf; Belirsiz Kimlikler. Çev., Nazlı Ökten. İstanbul: Metis Yayınları, (1993): 109-133.

Balibar, Etienne. “Sınıf Irkçılığı”. Irk, Ulus, Sınıf; Belirsiz Kimlikler. Çev., Nazlı Ökten. İstanbul: Metis Yayınlar1, (1993): 254-269.

Baumann, Gerd. Çokkültürlülük Bilmecesi: Ulusal, Etnik ve Dinsel Kimlikleri Yeniden Düşünmek. Çev., Iş1l Demirakın. Ankara: Dost Kitabevi, 2006.

Bostanc1, M. Naci. "Etnisite, Modernizm ve Milliyetçilik". Türkiye Günlüğü. 75 (2003): 5-32.

Bozay, Kemal. "Nation" und "Nationalismus" als Kernideologien der Herrschaftsabsicherung". Ungleichwertigkeitsideologien in der Einwanderungsgesellschaft. Bozay K., Borstel D. (eds) Edition Centaurus Jugend, Migration und Diversity., Wiesbaden: Springer VS, (2017): 41-61.

Çağlar, Nedret. "Postmodern Anlayışta Siyaset ve Kimlik". Süleyman Demirel Üniversitesi İİBF Dergisi. 13/3 (2008): 369-386.

Çancı, Haldun. "Değişmeyen Boyutları Bağlamında Milliyetçiliğe Teorik ve Kavramsal Bir Bakış". Süleyman Demirel Üniversitesi İİF Dergisi. 13/2 (2008): 105-116.

Erkal, Mustafa E. Sosyoloji (Toplumbilimi). İstanbul: Der Yayınları, 6. bs., 1995. 
Fuller, E. Graham. Demokrasi Tuză̆ı. Çev., Meral Gaspıralı. İstanbul: Altın Kitaplar Basimevi, 1996.

Gellner, Ernest. Uluslar ve Ulusçuluk. Çev., Büşra Ersanlı Behar ve Günay Göksu Özdoğan. İstanbul: İnsan Yayınları, 1992.

Gellner, Ernest. Milliyetçiliğe Bakış. Çev., Simten Coşar, Saltuk Özertürk ve Nalan Soyarık. İstanbul: İletişim Yayınları, 1998.

Giddens, Anthony. Elimizden Kaçıp Giden Dünya. Çev., Osman Akınhay. İstanbul: ALFA, 2000.

Gökalp, Emre. “Milliyetçilik: Kuramsal Bir Değerlendirme”. Anadolu Üniversitesi Sosyal Bilimler Dergisi. 7/1 (2007): 279-298.

Hobsbawm, Eric. “Giriş: Gelenekleri İcat Etmek”. Geleneğin İcadı. Haz., Eric Hobsbawm ve Terence Ranger. Çev., Mehmet Murat Şahin. İstanbul: Agora Kitaplığı, (2006): 1-18.

Hobsbawm, Eric. "Seri Üretim Gelenekler: Avrupa, 1870-1914”. Geleneğin İcadı. Haz., Eric Hobsbawm ve Terence Ranger. Çev., Mehmet Murat Şahin, İstanbul: Agora Kitaplığı, (2006): 305-356.

Kurubaş, Erol. “Etnik Sorunlar: Ulus-Devlet ve Etnik Gruplar Arasındaki Varoluşsal İlişki”. Doğu Batı. 11/44 (2008): 11-41.

Kymlicka, Will. Çokkültürlü Yurttaşlı/ Azınlık Haklarının Liberal Teorisi. Çev., Abdullah Yılmaz. İstanbul: Ayrıntı Yayınları, 1998.

Langewiesche, Dieter. Nation, Nationalismus, Nationalstaat in Deutschland und Europa. München: Beck, 2000.

Lückerath, Svenja. "Völkischer Nationalismus auf dem Vormarsch; Das Nationverstaendnisdes Front Nation und der Alternative für Deutschland im Vergleich", Institut für Politische Wissenschaft Selected Student Paper 68, Aachen, 2018.

Morgan, Prys. "Bir Ölümden Bir Bakışa: Romantik Dönemde Gal Geçmişinin Peşinde”. Geleneğin İcadı. Haz., Eric Hobsbawm ve Terence Ranger, Çev., Mehmet Murat Şahin. İstanbul: Agora Kitaplığı, (2006): 51-118.

Özkırımlı, Umut. Milliyetçilik Kuramları; Eleştirel Bir Bakış. Ankara: Doğu Batı Yayınları, 2008.

Ranger, Terence. “Sömürge Dönemi Afrika’sında Geleneğin İcadı”. Geleneğin İcadı. Haz., Eric Hobsbawm ve Terence Ranger. Çev., Mehmet Murat Şahin. İstanbul: Agora Kitaplığ 1 , (2006): 245-304.

Sağır, Meral Öztoprak, Serkan H. Akıllı. “Etnisite Kuramları ve Eleştirisi”. C.Ü. Sosyal Bilimler Dergisi. 28/1 (2004): 1-22.

Salzborn, Samuel. "Nation und Nationalismus $1 \mathrm{~m}$ 21. Jahrhundert”. Staat und Nation. Die Theorien der Nationalismusforschung in der Diskussion. hg., Samuel Salzborn. Stuttgart: Franz Steiner Verlag, (2011): 9-13

Smith, Anthony D. Ulusların Etnik Kökeni. Çev, Sonay Bayramoğlu ve Hülya Kendir. Ankara: Dost Kitabevi Yayınları, 2002. 
Smith, Anthony D. Milli Kimlik. Çev., Bahadır Sina Şener. İstanbul: İletişim Yayınları, 4. bs., 2007.

Trevor-Roper, Hugh. “Geleneğin İcadı: İskoçya’nın Hıghland Geleneği”. Geleneğin Ícadı. Haz., Eric Hobsbawm ve Terence Ranger. Çev., Mehmet Murat Şahin. İstanbul: Agora Kitaplığı, (2006): 19-50.

Üstel, Füsun. Makbul Vatandaş”ın Peşinde. İstanbul: İletişim Yayınları, 4. . bs., 2009.

Völkel, Bärbel. "Nationalismus - Ethnizismus - Rassismus? Fremde Blicke auf den genetisch-chronologischen Geschichtsunterricht". Historisches Lernen als Rassismuskritik. Hrsg: Christina Isabel Brüning, Lars Deile, Martin Lücke, Schwalbach: Wochenschau Verlag, (2016): 49-70.

Wallerstein, Immanuel. "Bağımsızlık Sonrası Siyah Afrika'da Toplumsal Çatışma: Yeniden Değerlendirilen Irk ve Statü Grubu Kavramları”. Irk, Ulus, Sinıf; Belirsiz Kimlikler. Çev., Nazlı Ökten. İstanbul: Metis Yayınları, (1993): 233-253.

Wallerstein, Immanuel. "Halklığın İnşası: Irkçılık, Milliyetçilik ve Etniklik”. Irk, Ulus, Sınıf; Belirsiz Kimlikler. Çev., Nazlı Ökten. İstanbul: Metis Yayınları, (1993): 91108.

Weichlein, Siegfried. Nationalbewegungen umd Nationalismus in Europa, 2. Auflage, 2013.

Yıldız, Süleyman. "Kimlik ve Ulusal Kimlik Kavramlarının Toplumsal Niteliği”. Milli Folklor. 19/74 (2007): 9-16. 
İNSAN\&İNSAN, Y11/Year 6, Say1/Issue 21, Yaz/Summer 2019, 413-430

DOI: https://doi.org/10.29224/insanveinsan.540654

\title{
The Origin of Nationalism: Ethnicity, Nation and Nation Relations
}

\author{
ABDULVAHAP AKINCI
}

Abstract: In Following the French Revolution, nationalism, which was one of the most rapidly spreading ideologies, changed the maps seriously and led to the emergence of a new world. The traditional means of providing the legitimacy of states are no longer sufficient. There is a new link between the state and the individual that is not in the traditional period. Nationalism became the most prominent tool in the modern era states. The debates on nationalism continue at a fast pace. In addition to those who argue that nations are natural phenomena and that their roots go back to ancient times, there are some who claim that nations were built under some social, economic and cultural conditions that emerged in the modern era. Some thinkers acknowledge that in the modern sense, nations are a modern phenomenon as a result of a building process, they argue that ethnic origins have a great impact in the construction process of the nation. In this study, the process of building of nations will be examined by evaluating whether there is a connection between the emergence of nations and ethnic origins. It will be tried to make a situation evaluation in the societies which have the same ethnic origins and international ethnic backgrounds.

Keywords: Nation, Nationalism, Nation state, Ethnicity. 